he the case in the various series of cases which I have seen reported. This right-sided involvement opens the door for constant mistakes in dianosis during pregnaney or in the carly puerperium. The differential diagnosis between inflammatory conditions of the abdomen during pregnancy is very difficult, if not impossible, and unnecessinry operations will undoubtedly be frequently performed on account of the impossibility of distinguishing aceurately between an acute attack of ajpendicitis and an acute pyelitis. 'Time will, of course, show the true diagnosis, but the history of acute appendicitis during pregnancy or in the early days of the puerperium shows such a large percentage of fatal cases that time is the one factor which camnot be given, and it is unquestionably safer to operate unnecessarily for a pyelitis than to delay operation on a gangrenous appendix.

\section{A CASE OF PYELITIS DURING PREGNANCY.*}

$$
\text { BY С. I. НАRะ, м.D. }
$$

Mrs. 5289; age thirty-eight; married five months. Catamenia began at seventeen and one-half years, and has always been normal. Iast menstruation Oct. 26. She had always been perfectly well in erery way, and wats a well, strong looking woman. She was first seen Mareh 20, when her story was that urination had occurred regularly five or six times a day up to Mareh 14, when without any known cause, after going seven and one-half hours without voiding the urine, she suddenly begam to pass it every half hour day and night with dysuria and tenesmus, and that condition haid existed up to the time I saw her, although the tenesmus was somewhat better. She was a careful observer, and had seen a few specks of blood in the urine at various times. Whe had kept the daily secretion above $60 \mathrm{oz}$. sinee the fourteenth. There had been no renal eolic, but there had been an ache in the region of the right kidney, especially in the back, for two days. The urine had been elear before the fourteenth, but eloudy as a rule, though clear at times, since the fourteenth. Her weight was $128 \mathrm{lb}$. There had been no edema, headache or nausea, or any other symptoms except the above. She was the fifth of eight children, two of whom had died in infancy. 'Both deaths were satd to have been eaused by pueumonia. Her mother died of tubereulosis when the patient was eleven years old. Examination of urine taken by ratheter Mareh 20 had about 2 dr. of practically solid pus in $3 \frac{1}{2}$ oz. of slightly acid urine; specifie gravity 1,010 and a good trace of albumin. There was a moderate amount of blood and bacteria, very few round cells and a few parement cells. Probable dingnosis: l'us in the right kidney. She was told to stay quietly in bed and wateh the urine for intermittent pyuria. She was given $7 \frac{1}{2} \mathrm{gr}$. urotropin three times daily, and teold to take all the liquid she possibly could. On March 23 she had a chill at 11 A.M. and was ehilly at 5 P.M., when I next, saw her, at, which time pulse was 108 and temperature 99.4. For a few days she had profuse sweating and looked flushed in the face although she felt perfeetly well. By Mareh 25, urintition had dropped to once every two to four hours dity and night. Tenesmus had ended and there was no dysuria. Pyuria which had been steady, ended on this day. she had voided from 2 to $10 \mathrm{oz}$. each time, and passed $54 \mathrm{oz}$. in twenty-four hours. On this day

* Read at the Obstetrieal Society of lioston, Dee. 18, 1906. she had her highest temperature and pulse, which at $1.30 \mathrm{r}$.M. was, pulse, 116 ; temperature, 101 . 'The urine on March 24 was examined by Dr. Garcenu, who reported: Total twenty-four-hour amount, (60) oz; total urea, 20.34. Speecific gravity, 1,005. Very slight trace of albumin, much sediment, which consisted chiefly of pus, many round and medium si\%e epithelial cells which were gramular. Few cordate eells. Few hyaline and gramular catsts. Mamy bateteria. Many diplocoesi. No gonocoeci. No tuberele bacilli. Many subsecquent examinations were made by both l)r. (Aarceatu and myself, which I will not report in detail, as the urine gridually (eleared up), and by $\Lambda$ pril 5 was normal. The urine was also normal on all subsequent examinations during her pregnimey and her puerperium. She was up and about after $\Lambda_{p}$ ril 1 and sinee then has had no trouble although she was carefully watehed until about at month affer her baby wats born. She had a normal and easy labor July 2:3, which was followed by normal convaleseenee.

\section{Hepurty of Sorietieg.}

\section{OBSSTETRICAL SOCHETY OF PHILAIDLPIIIA.}

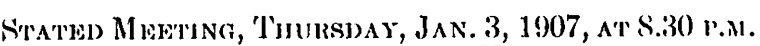
The President, J)r. Whamer Krusen, in the chaIR.

\section{VAGINAT, HYSTERECTOMY.}

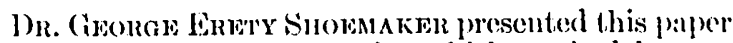
in which the conditions under which vaginal hysterectomy was considered, the operation of choice as contrasted with hystereetomy through the abdomen, were illustrated by the histories of ten cases last operated upon. All made normal recovery. Nearly all the patients had passed through the menopatuse. Fibromata not larger than a child's head which gave trouble from pressure or from hemorrhage were considered suitable for vaginal hysterectomy, especially in stout women with poor hearts. In procidentia of old women where the uterus was diseased, especially in the presence of adenoma of the endometrium, the uterus was removed through the vagina as a preliminary to thorough repair of the pelvie outlet, including the anterior and posterior vaginal walls high up. Where the uterus is not diseased vaginal hysterectomy is not usually an element in the operation for procidentia. Great stress was laid upon the importance of pilying heed to post-menopmusal bleeding and cases were cited bearing upon this conditios. 'The dinger of overlooking early malignancy in the examination of serapings was emphasized. That only a few and perhalys none of the tiny pieces removed by the euretite might happen to contain structure from which a diagrnosis of malignancy eould be made, if present, was shown by reference to a ease in which Dr. Shoemaker had removed the uterus for eonstantly increasing hemorrhage at the ane of forty-one under a clinical diagnosis of malignant adenoma. 'The mieroseopieal rejort pronounced the andenoma benign, but three years later there is reported a recurrence of malignant disease in the vaginal sear which proved the elinieal diagnosis to have been more correct than the microscopical.

The method usually adopted for removing the uterus by the vaginal is to eatuterize freely if there is suspieion of malignancy, ligate with silk low down and to use the elamps high up, morecllating the mass when it is too large to deliver easily. 'The operation was considered not suffeiently complete for malignant disease of the 